\title{
Hydrogen Desorption Exceeding Ten Weight Percent from the New
}

\section{Quaternary Hydride $\mathrm{Li}_{3} \mathrm{BN}_{2} \mathrm{H}_{8}$}

Frederick E. Pinkerton, ${ }^{* \dagger}$ Gregory P. Meisner, ${ }^{\dagger}$ Martin S. Meyer, ${ }^{\dagger}$ Michael P. Balogh, ${ }^{\S}$

\author{
and Matthew D. Kundrat ${ }^{\ddagger}, \#$
}

Materials and Processes Laboratory and Chemical and Environmental Sciences Laboratory,

General Motors Research and Development Center, 30500 Mound Road, Warren, MI 48090-9055

*frederick.e.pinkerton@gm.com

\section{Supporting information}

\section{Materials and methods}

$\mathrm{LiNH}_{2}$ powder (95\% purity) was obtained from Aldrich Chemicals. Chemical analysis yields 30.7 $\mathrm{wt} \% \mathrm{Li}, 58.0 \mathrm{wt} \% \mathrm{~N}$, and $8.4 \mathrm{wt} \% \mathrm{H}$, compared to the theoretical $\mathrm{LiNH}_{2}$ composition of $30.2 \mathrm{wt} \% \mathrm{Li}$, $61.0 \mathrm{wt} \% \mathrm{~N}$, and $8.8 \mathrm{wt} \% \mathrm{H}$. The analysis is consistent with $\mathrm{LiNH}_{2}$ with about $5 \mathrm{wt} \% \mathrm{Li}_{2} \mathrm{O}$ impurity. The presence of $\mathrm{Li}_{2} \mathrm{O}$ is confirmed by $\mathrm{x}$-ray diffraction.

$\mathrm{LiBH}_{4}$ powder (95\% purity) was obtained from Lancaster Research Chemicals. Chemical

analysis yields $31.5 \mathrm{wt} \% \mathrm{Li}, 49 \mathrm{wt} \% \mathrm{~B}$, and $17.7 \mathrm{wt} \% \mathrm{H}$, compared to the theoretical $\mathrm{LiBH}_{4}$ composition of $31.8 \mathrm{wt} \% \mathrm{Li}, 49.6 \mathrm{wt} \% \mathrm{~B}$, and $18.5 \mathrm{wt} \% \mathrm{H}$. 
Powders were ball milled in a SPEX 8000 Mixer/Mill using a hardened steel ball mill jar containing one large (8.4 g) and two small (1.0 g) steel balls. The jar was loaded and sealed while in an Ar inert gas glove box.

Mixed $\mathrm{LiNH}_{2}-\mathrm{LiBH}_{4}$ powders were made either by combining the powders and thoroughly mixing by hand (Figure 2) or by combining the powders in a ball mill jar without including the milling balls, and mixing in the SPEX 8000 Mixer/Mill for 10 min (Figure 3).

\section{Measurements}

X-ray diffraction (XRD) analysis was performed with a Bruker AXS General Area Detector Diffractometer System (GADDS). Samples were loaded within a glove box into $1 \mathrm{~mm}$ diameter quartz tubes, which were sealed with clay and transported to the diffractometer. Temperature-dependent in situ XRD was performed in the same instrument using a special sample cell and furnace described previously. ${ }^{1 \mathrm{~S}}$ In order to obtain a higher resolution diffraction pattern for $\mathrm{Li}_{3} \mathrm{BN}_{2} \mathrm{H}_{8}$, one powder sample was prepared inside a glove box on a standard x-ray diffraction slide and covered by a thin plastic film to protect it from exposure to air. This sample was measured using a Siemens D5000 powder diffractometer. Several scans were performed sequentially, and the absence of changes in the diffraction pattern demonstrated that no oxidation or hydrolysis of the sample took place during data acquisition.

Fig. 1S shows a room temperature GADDS XRD pattern from the dehydrided product obtained by heating $\mathrm{Li}_{3} \mathrm{BN}_{2} \mathrm{H}_{8}$ to $346^{\circ} \mathrm{C}$ in the in-situ XRD system. We identify the major peaks (filled circles) as arising from a new polymorph of $\mathrm{Li}_{3} \mathrm{BN}_{2}$ because they closely resemble the XRD pattern of a quenched high-pressure $\mathrm{Li}_{3} \mathrm{BN}_{2}$ polymorph. ${ }^{2 \mathrm{~S}}$ This set of peaks, with the same relative intensities, occurs in all examples of dehydrided products and thereby represents a single phase with a well-defined crystal structure. A less intense set of peaks (crosses) can be indexed to the high temperature polymorph of $\mathrm{Li}_{3} \mathrm{BN}_{2} \cdot{ }^{3 \mathrm{~S}}$ The mixture of $\mathrm{Li}_{3} \mathrm{BN}_{2}$ polymorphs shown in Fig. $1 \mathrm{~S}$ is characteristic of the XRD results 
from a large number of dehydrided samples. A very small quantity of $\mathrm{Li}_{2} \mathrm{O}$ is also commonly observed. In some cases, there are additional diffraction lines from another, as yet unidentified, minor phase (or phases), with diffraction peaks at about $18.6^{\circ}, 22.8^{\circ}, 29.6^{\circ}, 40.0^{\circ}, 50.6^{\circ}, 56.2^{\circ}, 58.0^{\circ}, 63.0^{\circ}, 69.6^{\circ}$, $71.4^{\circ}$, and $71.6^{\circ}$. We have not succeeded in indexing these minor phase peaks to any known compounds in the $\mathrm{x}$-ray diffraction or crystal structure ${ }^{4 \mathrm{~S}}$ databases.

Gravimetric measurements of gas evolution were performed using a Cahn Model 2151 highpressure thermogravimetric analyzer (TGA). Approximately $300 \mathrm{mg}$ of powder was loaded into a quartz sample bucket in a glove box. The bucket was then filled with anhydrous pentane to protect the sample from air exposure while the sample was loaded into the TGA. (X-ray diffraction analysis of a test sample confirmed that the sample was unchanged after immersion in and subsequent evaporation of the pentane.) The TGA was thoroughly purged with He gas while the pentane evaporated. The sample was heated in flowing $\mathrm{He}$ gas to a temperature of $350^{\circ} \mathrm{C}$ and held at that temperature. Gas desorption was directly measured as weight loss by the sample during heating, corrected for non-gravitational forces due to gas buoyancy, gas flow velocity, and electrobalance temperature. ${ }^{5 \mathrm{~S}}$ A differentially pumped mass spectrometer operated as a residual gas analyzer (RGA) monitored the composition of the exhaust gas. The RGA captured eight mass channels corresponding to $2\left(\mathrm{H}_{2}\right), 4(\mathrm{He}), 16$ (the $\mathrm{NH}_{2}{ }^{+}$gas fragment of $\mathrm{NH}_{3}$, or $\left.\mathrm{CH}_{4}\right), 17\left(\mathrm{NH}_{3}\right.$ or the $\mathrm{OH}$ gas fragment of $\left.\mathrm{H}_{2} \mathrm{O}\right), 18\left(\mathrm{H}_{2} \mathrm{O}\right), 28\left(\mathrm{~N}_{2}\right.$ or $\left.\mathrm{CO}\right), 32\left(\mathrm{O}_{2}\right)$, and $44\left(\mathrm{CO}_{2}\right)$ amu. RGA detection of gas evolved from the sample was delayed by about 3 min compared to the corresponding TGA weight loss due to the transit time of the gas flow between the TGA sample chamber and the RGA inlet.

Volumetric measurements were performed using a Gas Reaction Controller (GRC) made by Advanced Materials Corporation, described previously. ${ }^{6 S, 7 S}$ The amount of hydrogen released from the sample was measured by first evacuating the sample chamber at ambient temperature, and then heating the sample to $364^{\circ} \mathrm{C}$ at $0.5^{\circ} \mathrm{C} / \mathrm{min}$ while monitoring the pressure and temperature in the chamber. The amount of desorbed gas was calculated as a function of time from the pressure, temperature, and 
chamber volume. The final amount of gas evolved was determined only after the experiment reached equilibrium conditions at $364^{\circ} \mathrm{C}$.

Thermal behavior was measured using a Perkin-Elmer System 7 differential scanning calorimeter (DSC) high-pressure cell located within an Ar inert gas glove box. $2.05 \mathrm{mg}$ of $\mathrm{Li}_{3} \mathrm{BN}_{2} \mathrm{H}_{8}$ powder was placed within an aluminum sample pan and heated at $10^{\circ} \mathrm{C} / \mathrm{min}$ from $150^{\circ} \mathrm{C}$ to $400^{\circ} \mathrm{C}$ in $100 \mathrm{kPa}$ of $\mathrm{H}_{2}$ gas flowing at $50 \mathrm{cc} / \mathrm{min}$. After evolving hydrogen during the first scan, a second scan on the dehydrided material was immediately performed under identical conditions to serve as a background scan. The net heat flow after background subtraction, shown in Fig. 2S, suggests that the dehydriding process is exothermic. Interpretation of the DSC result is difficult due to simultaneous ammonia release, formation of a solid product, and the possible effects of the released hydrogen and ammonia on the calorimeter response. Fig. $2 \mathrm{~S}$ indicates that the enthalpy of reaction $\Delta \mathrm{H}$ is about $-52 \mathrm{~kJ} / \mathrm{mole}_{2}$.

\section{References for Supporting Information}

1S. Balogh, M. P.; Tibbetts, G. G.; Pinkerton, F. E.; Meisner, G. P.; Olk, C. H. J. Alloys Comp. 350, $136(2003)$.

2S. DeVries, R. C.; Fleischer, J. F. Mat. Res. Bull. 4, 433 (1969).

3S. Yamane, H.; Kikkawa, S.; Horiuchi, H.; Koizumi, M. J. Solid State Chem. 65, 6 (1986).

4S. Villars, P. Pearson's Handbook Desk Edition (ASM International, 1997), p. 771.

5S. Pinkerton, F. E.; Meyer, M. S.; Tibbetts, G. G.; Chahine, R. Proc. 11th Canadian Hydrogen Conference, Victoria, BC, Canada, pp 633-642 (2001).

6S. Tibbetts, G. G.; Meisner, G. P.; Olk, C. H. Carbon 39, 2291 (2001). 
7S. Meisner, G. P.; Tibbetts, G. G.; Pinkerton, F. E.; Olk, C. H.; Balogh, M. P. J. Alloys Comp. 337, 254 (2002).

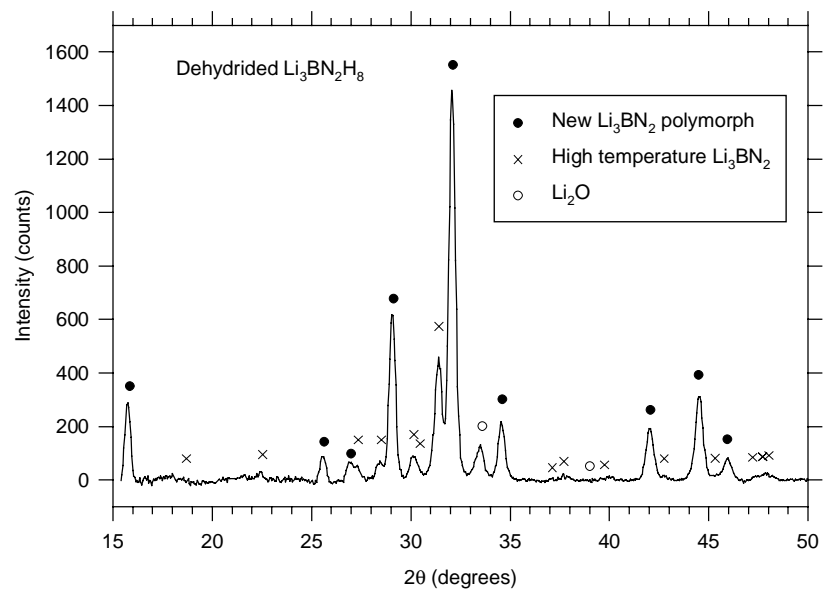

Fig. 1S: Room temperature x-ray diffraction pattern of the reaction product obtained by dehydriding $\mathrm{Li}_{3} \mathrm{BN}_{2} \mathrm{H}_{8}$ at $346^{\circ} \mathrm{C}$ in the in-situ GADDS system. The product consists of a new polymorph of $\mathrm{Li}_{3} \mathrm{BN}_{2}$, a smaller quantity of the high temperature form of $\mathrm{Li}_{3} \mathrm{BN}_{2}$, and a very small amount of $\mathrm{Li}_{2} \mathrm{O}$.

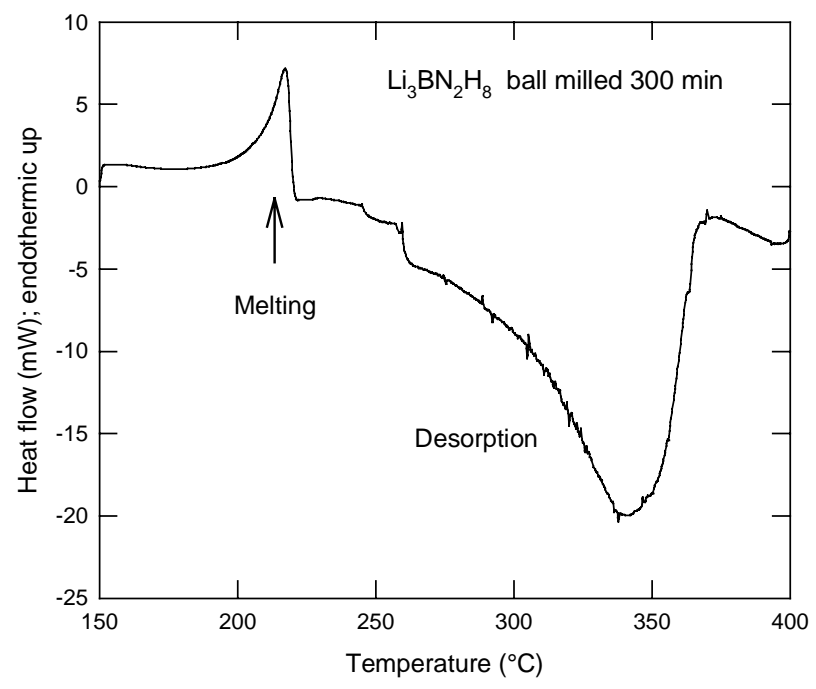


Figure 2S: Differential scanning calorimeter (DSC) scan of $\mathrm{Li}_{3} \mathrm{BN}_{2} \mathrm{H}_{8}$ prepared by ball milling mixed 2 $\mathrm{LiNH}_{2}+\mathrm{LiBH}_{4}$ powder for 300 min. Melting of the $\mathrm{Li}_{3} \mathrm{BN}_{2} \mathrm{H}_{8}$ phase appears as an endothermic peak above $200^{\circ} \mathrm{C}$. A larger exothermic peak above $250^{\circ} \mathrm{C}$ is associated with hydrogen desorption.

Pinkerton et al. 